\title{
Recycling of brewer's spent grain as biosorbent by nitro-oxidation for uranyl ions removal from wastewater
}

Yi Su', Marco Wenzel ${ }^{a}$, Silvia Paasch ${ }^{b}$, Markus Seifert ${ }^{a}$, Wendelin Böhm ${ }^{c}$, Thomas Doert $^{d}$, Jan J. Weigand ${ }^{a^{*}}$

${ }^{\text {a }}$ Chair of Inorganic Molecular Chemistry, TU Dresden, 01062 Dresden, Germany

${ }^{\mathrm{b}}$ Chair of Bioanalytical Chemistry, TU Dresden, 01062 Dresden, Germany

${ }^{\mathrm{c}}$ Chair of Food Chemistry, TU Dresden, 01062 Dresden, Germany

${ }^{\mathrm{d}}$ Chair of Inorganic Chemistry II, TU Dresden, 01062 Dresden, Germany

${ }^{*}$ Corresponding author

E-mail address: jan.weigand@tu-dresden.de (J.J. Weigand) 


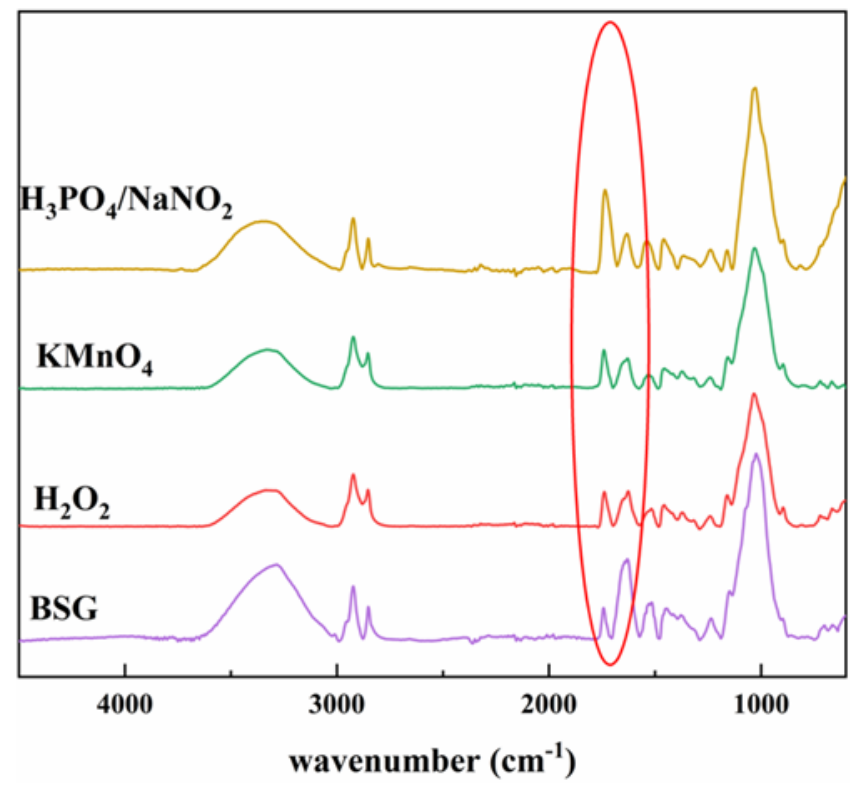

Figure S1. FT-IR spectra of oxidized products by different oxidation methods. $\mathrm{H}_{2} \mathrm{O}_{2}$ method: 2 g BSG, $10 \mathrm{~mL} 35 \mathrm{wt} \% \mathrm{H}_{2} \mathrm{O}_{2}, 0.4 \mathrm{~mL} 1 \mathrm{M} \mathrm{HCl}$, reflux at $100{ }^{\circ} \mathrm{C}$ for $2 \mathrm{~h}$. $\mathrm{KMnO}_{4}$ method: $1 \mathrm{~g} \mathrm{BSG}, 0.18 \mathrm{~g} \mathrm{KMnO}_{4}, 20 \mathrm{~mL} 0.15 \mathrm{M} \mathrm{H}_{2} \mathrm{SO}_{4}$ at $60{ }^{\circ} \mathrm{C}$ for $2 \mathrm{~h}$. $\mathrm{H}_{3} \mathrm{PO}_{4} / \mathrm{NaNO}_{2}$ method: $1 \mathrm{~g}$ BSG, $16 \mathrm{~mL} 85 \mathrm{wt} \% \mathrm{H}_{3} \mathrm{PO}_{4}, 0.8 \mathrm{~g} \mathrm{NaNO} \mathrm{Na}_{2}$ at room temperature for $16 \mathrm{~h}$.

The $v(\mathrm{COOH})$ vibration at $1742 \mathrm{~cm}^{-1}$ for $\mathrm{BSG}$ and $1732 \mathrm{~cm}^{-1}$ for OBSG has been confirmed by the shifts upon $\mathrm{D}^{+}$labelling. Typically, $30 \mathrm{mg}$ adsorbents were mixed with $2 \mathrm{~mL} \mathrm{D}_{2} \mathrm{O}$ in $2 \mathrm{~mL}$ centrifuge tube for $64 \mathrm{~h}$. Then the mixture was centrifuged, the supernatant was discarded, and the obtained solid was dried at $60^{\circ} \mathrm{C}$ for $12 \mathrm{~h}$. The $\mathrm{D}^{+}$ labelling samples are named as $\mathrm{BSG}-\mathrm{D}_{2} \mathrm{O}$ and $\mathrm{OBSG}-\mathrm{D}_{2} \mathrm{O}$ and subjected to FT-IR measurement using a single beam Fourier transform infrared VERTEX 70 spectrometer 
(Bruker). The entire spectra were recorded over the range of 4500 to $600 \mathrm{~cm}^{-1}$ with a resolution of $4 \mathrm{~cm}^{-1}$ and averaged over 32 scans. Within the particularly interested area (2000-1200 $\left.\mathrm{cm}^{-1}\right)$, detailed spectra with a resolution of $1 \mathrm{~cm}^{-1}$ and averaged over 64 scans were also measured (Figure S2).

Table S1. Shifts of $v(\mathrm{COOH})$ vibration in BSG and OBSG FT-IR spectra upon $\mathrm{D}^{+}$ labelling.

\begin{tabular}{llll}
\hline & $v$ (origin) & $v\left(\mathrm{D}_{2} \mathrm{O}\right)$ & $\Delta v$ \\
\hline BSG & $1742 \mathrm{~cm}^{-1}$ & $1739 \mathrm{~cm}^{-1}$ & $3 \mathrm{~cm}^{-1}$ \\
OBSG & $1732 \mathrm{~cm}^{-1}$ & $1729 \mathrm{~cm}^{-1}$ & $3 \mathrm{~cm}^{-1}$ \\
\hline
\end{tabular}

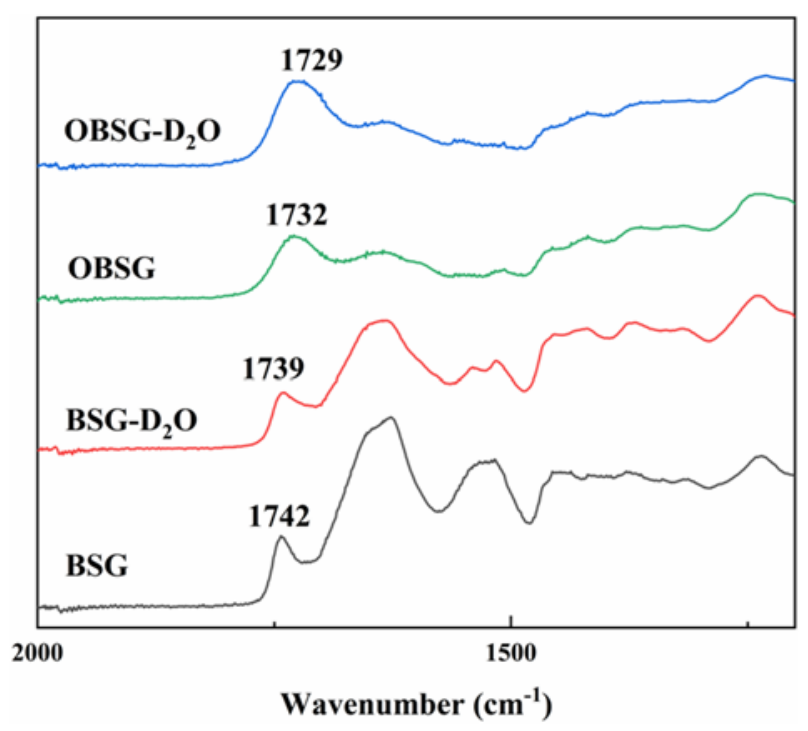

Figure S2. FT-IR spectra of BSG and OBSG with or without $\mathrm{D}^{+}$labelling. For $\mathrm{D}^{+}$

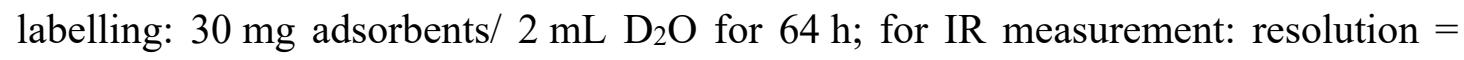
$1 \mathrm{~cm}^{-1}$, averaged over 64 scans. 
Table S2. Elemental analysis of BSG and OBSG.

\begin{tabular}{lllllll}
\hline & $\mathrm{N}(\%)$ & $\mathrm{C}(\%)$ & $\mathrm{H}(\%)$ & $\mathrm{S}(\%)$ & Mineral (\%) & $\mathrm{O}(\%)$ \\
\hline BSG & $5.1 \pm 0.1$ & $49.1 \pm 0.1$ & $6.1 \pm 0.2$ & $0.3 \pm 0.1$ & $1.4 \pm 0.1$ & $38.0 \pm 0.6$ \\
OBSG & $1.1 \pm 0.1$ & $42.6 \pm 0.8$ & $5.4 \pm 0.1$ & $0.1 \pm 0.1$ & $1.0 \pm 0.1$ & $49.8 \pm 1.2$ \\
\hline
\end{tabular}

Table S3. Mineral elements content $(\mathrm{mg} / \mathrm{kg})$ of BSG and OBSG.

\begin{tabular}{lllllllllll}
\hline & $\mathrm{K}$ & $\mathrm{Na}$ & $\mathrm{P}$ & $\mathrm{Ca}$ & $\mathrm{Fe}$ & $\mathrm{Mg}$ & $\mathrm{Mn}$ & $\mathrm{Zn}$ & $\mathrm{Si}$ & Mineral (\%) \\
\hline BSG & $808 \pm 0.2$ & $9 \pm 1$ & $5284 \pm 3$ & $1096 \pm 2$ & 0 & $1487 \pm 0.2$ & 0 & 0 & $5184 \pm 0.4$ & $1.4 \pm 0.1$ \\
OBSG & 0 & 0 & $760 \pm 30$ & $1.1 \pm 0.1$ & 0 & 0 & 0 & 0 & $9400 \pm 270$ & $1.0 \pm 0.1$ \\
\hline
\end{tabular}

Errors are those obtained from the ICP measurements.

Table S4. Comparison of $\mathrm{pH}$ value of uranyl ions solution before and after adsorption.

\begin{tabular}{lll}
\hline Experiment Number & $\mathrm{pH}$ (before) & $\mathrm{pH}$ (after) \\
\hline 1 & 4.7 & 4.2 \\
2 & 3.9 & 3.2 \\
3 & 2.8 & 2.7 \\
4 & 2.3 & 2.3 \\
5 & 1.2 & 1.3 \\
\hline
\end{tabular}




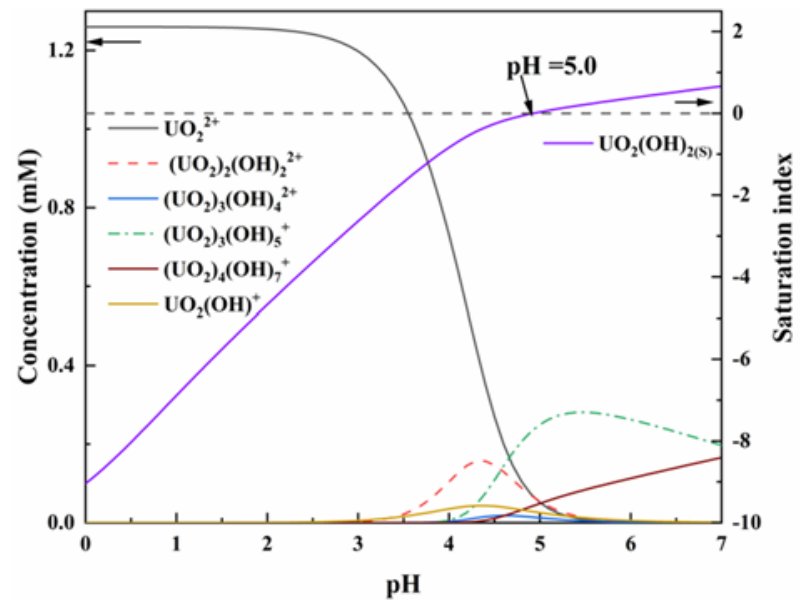

Figure S3. Distribution diagram of uranyl acetate solution. For input data, $\mathrm{c}_{0}(\mathrm{U})=$ $300 \mathrm{mg} / \mathrm{L}=1.26 \mathrm{mM}, \mathrm{c}\left(\mathrm{CH}_{3} \mathrm{COO}^{-}\right)=2.52 \mathrm{mM}$, alkalinity: no specification, $\mathrm{pH}=$ $0-7.0$, increment $=0.1$, calculated by Visual MINTEQ 3.1. ${ }^{1}$ 
Table S5. Results of statistical methods using for comparing pseudo-first-order and pseudo-second-order kinetic model (rotation speed $=60 \mathrm{rpm}$ ).

\begin{tabular}{|c|c|c|c|c|c|}
\hline Preferred model & \multicolumn{5}{|c|}{ Model Name } \\
\hline AIC & \multicolumn{5}{|c|}{ Pseudo-first-order kinetic model } \\
\hline $\mathrm{BIC}$ & \multicolumn{5}{|c|}{ Pseudo-first-order kinetic model } \\
\hline F-Test & \multicolumn{5}{|c|}{ Pseudo-first-order kinetic model } \\
\hline Akaike Information Criterion (AIC) $^{1}$ & $R S S$ & $N$ & $p$ & $A I C^{2}$ & $\begin{array}{l}\text { Akaike's } \\
\text { weights }^{3}\end{array}$ \\
\hline Pseudo-first-order kinetic model & 3.0747 & 8 & 2 & 4.3501 & 0.9999 \\
\hline Pseudo-second-order kinetic model & 29.9194 & 8 & 2 & 22.5525 & 0.0001 \\
\hline Bayesian Information Criteria (BIC) test ${ }^{4}$ & $R S S$ & $N$ & $p$ & $B I C^{5}$ & $\triangle B I C$ \\
\hline Pseudo-first-order kinetic model & 3.0747 & 8 & 2 & -1.4116 & 0 \\
\hline Pseudo-second-order kinetic model & 29.9194 & 8 & 2 & 16.7909 & 18.2025 \\
\hline F-Test ${ }^{6}$ & $R S S$ & $D_{1}$ & & $F^{7}$ & Prob $>$ F \\
\hline Pseudo-first-order kinetic model & 3.0747 & 6 & & 0.1028 & 0.9930 \\
\hline Pseudo-second-order kinetic model & 29.9194 & 6 & & & \\
\hline
\end{tabular}

1. Pseudo-first-order kinetic model has lower $A I C$ value and so is more likely to be correct. This model is 8966.14 times more likely to be correct.

2. $A I C=N \ln \left(\frac{R S S}{N}\right)+2 p+\frac{2 p(p+1)}{N-p-1}$, where $N$ is the number of data points and $p$ is the number of free parameters to be estimated.

3. Akaike's weight $=\frac{e^{-0.5 \Delta A I C}}{1+e^{-0.5 \Delta A I C}}$, where $\triangle A I C$ is the deference between two $A I C$ values.

4. Pseudo-first-order kinetic model has lower $B I C$ value and so is more likely to be correct. BIC difference $(\triangle B I C)$ more than 10 gives decisive conclusion that pseudo-first-order kinetic model is correct.

5. $\quad B I C=N \ln \left(\frac{R S S}{N}\right)+p \ln (N)$, and $\triangle B I C$ is the deference between two $B I C$ values.

6. At the 0.05 significance level, pseudo-first-order kinetic model is more likely to be correct.

7. $F=R S S_{1} / R S S_{2}$, where $R S S_{1}$ and $R S S_{2}$ are the residual sum of squares of pseudo-first-order kinetic and pseudo-second-order kinetic model, respectively. 

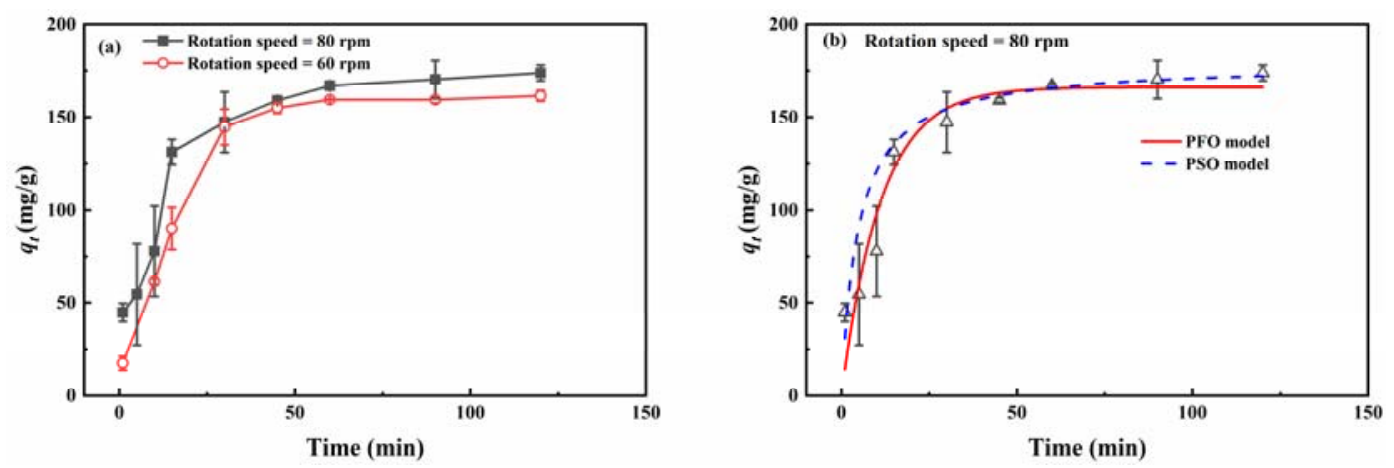

Figure S4. (a) Effect of rotation speed on the adsorption kinetics. For adsorption, $2 \mathrm{mg}$ OBSG/ $2 \mathrm{~mL}$ solution, $\mathrm{c}_{0}(\mathrm{U})=300 \mathrm{mg} / \mathrm{L}, \mathrm{pH}=4.7$, room temperature, and (b) nonlinear fitting of pseudo-first-order (PFO) and pseudo-second-order (PSO) kinetic model of the kinetic data for rotation speed $=80 \mathrm{rpm}$.

Table S6. Parameters of kinetic models at higher rotation speed. For adsorption, $2 \mathrm{mg}$ OBSG/ $2 \mathrm{~mL}$ solution, $\mathrm{c}_{0}(\mathrm{U})=300 \mathrm{mg} / \mathrm{L}, \mathrm{pH}=4.7$, rotation speed $=80 \mathrm{rpm}$, room temperature.

\begin{tabular}{lllllll}
\hline $\begin{array}{l}\text { Pseudo-first-order } \\
\text { kinetic model }\end{array}$ & $k_{l}\left(\mathrm{~min}^{-1}\right)$ & $\begin{array}{l}q_{e, \text { exp }} \\
(\mathrm{mg} / \mathrm{g})\end{array}$ & $\begin{array}{l}q_{e, \text { call }} \\
(\mathrm{mg} / \mathrm{g})\end{array}$ & $R^{2}$ & $R S S$ & $\chi^{2}$ \\
\hline & 0.0888 & 167.0 & 166.2 & 0.9107 & 60.0 & 8.6 \\
\hline $\begin{array}{l}\text { Pseudo-second- } \\
\text { order kinetic model }\end{array}$ & $\begin{array}{l}k_{2} \\
\left(\mathrm{~g} \cdot \mathrm{mg}^{-1} \cdot \mathrm{min}^{-1}\right)\end{array}$ & $\begin{array}{l}q_{e, \text { exp }} \\
(\mathrm{mg} / \mathrm{g})\end{array}$ & $\begin{array}{l}q_{e, \text { cal } 2} \\
(\mathrm{mg} / \mathrm{g})\end{array}$ & $R^{2}$ & $R S S$ & $\chi^{2}$ \\
\hline & 0.0012 & 167.0 & 179.0 & 0.9692 & 20.7 & 3.0 \\
\hline
\end{tabular}


Table S7. Results of statistical methods using for comparing pseudo-first-order and pseudo-second-order kinetic model (rotation speed $=80 \mathrm{rpm}$ ).

\begin{tabular}{|c|c|c|c|c|c|}
\hline Preferred model & \multicolumn{5}{|c|}{ Model Name } \\
\hline AIC & \multicolumn{5}{|c|}{ Pseudo-second-order kinetic model } \\
\hline $\mathrm{BIC}$ & \multicolumn{5}{|c|}{ Pseudo-second-order kinetic model } \\
\hline F-Test & \multicolumn{5}{|c|}{ Pseudo-second-order kinetic model } \\
\hline Akaike Information Criterion (AIC) $^{1}$ & $R S S$ & $N$ & $p$ & $A I C^{2}$ & $\begin{array}{l}\text { Akaike's } \\
\text { weight }^{3}\end{array}$ \\
\hline Pseudo-first-order kinetic model & 60.0214 & 9 & 2 & 27.8759 & 0.0082 \\
\hline Pseudo-second-order kinetic model & 20.6690 & 9 & 2 & 18.2827 & 0.9918 \\
\hline Bayesian Information Criteria (BIC) test ${ }^{4}$ & $R S S$ & $N$ & $p$ & $B I C^{5}$ & $\triangle B I C$ \\
\hline Pseudo-first-order kinetic model & 60.0214 & 9 & 2 & 23.6676 & 9.5932 \\
\hline Pseudo-second-order kinetic model & 20.6690 & 9 & 2 & 14.0744 & 0 \\
\hline F-Test ${ }^{6}$ & $R S S$ & $D F$ & & $F^{7}$ & Prob $>F$ \\
\hline Pseudo-first-order kinetic model & 60.0214 & 7 & & 2.9039 & 0.0915 \\
\hline Pseudo-second-order kinetic model & 20.6690 & 7 & & & \\
\hline
\end{tabular}

1. Pseudo-second-order kinetic model has lower $A I C$ value and is more likely to be correct. This model is 121.101 times more likely to be correct.

2. $A I C=N \ln \left(\frac{R S S}{N}\right)+2 p+\frac{2 p(p+1)}{N-p-1}$, where $N$ is the number of data points and $p$ is the number of free parameters to be estimated.

3. Akaike's weight $=\frac{e^{-0.5 \Delta A I C}}{1+e^{-0.5 \Delta A I C}}$, where $\triangle A I C$ is the deference between two $A I C$ values.

4. Pseudo-second-order kinetic model has lower $B I C$ value and is more likely to be correct. $\triangle B I C$ gives a strong support to pseudo-second-order kinetic model.

5. $\quad B I C=N \ln \left(\frac{R S S}{N}\right)+p \ln (N)$, and $\triangle B I C$ is the deference between two $B I C$ values.

6. At the 0.05 significance level, pseudo-second-order kinetic model is more likely to be correct.

7. $F=R S S_{1} / R S S_{2}$, where $R S S_{1}$ and $R S S_{2}$ are the residual sum of squares of pseudo-first-order kinetic and pseudo-second-order kinetic model, respectively. 
Table S8. Results of statistical methods using for comparing R-P model and Freundlich model.

\begin{tabular}{|c|c|c|c|c|c|}
\hline Preferred model & \multicolumn{5}{|c|}{ Model Name } \\
\hline AIC & \multicolumn{5}{|c|}{ Freundlich model } \\
\hline $\mathrm{BIC}$ & \multicolumn{5}{|c|}{ Inconclusive } \\
\hline F-Test & \multicolumn{5}{|c|}{ Freundlich model } \\
\hline $\begin{array}{lll}\text { Akaike } & \text { Information } & \text { Criterion } \\
(\mathrm{AIC})^{1} & & \end{array}$ & $R S S$ & $N$ & $p$ & $A I C^{2}$ & $\begin{array}{l}\text { Akaike's } \\
\text { weight }^{3}\end{array}$ \\
\hline Freundlich model & 42.5480 & 11 & 2 & 24.3087 & 0.8790 \\
\hline R-P model & 37.9033 & 11 & 3 & 28.2752 & 0.1210 \\
\hline $\begin{array}{l}\text { Bayesian Information Criteria (BIC) } \\
\text { test }^{4}\end{array}$ & $R S S$ & $N$ & $p$ & $B I C^{5}$ & $\triangle B I C$ \\
\hline Freundlich model & 42.5480 & 11 & 2 & 22.0738 & 0 \\
\hline R-P model & 37.9033 & 11 & 3 & 23.2001 & 1.1264 \\
\hline \multirow[t]{2}{*}{ F-Test ${ }^{6}$} & $F^{7}$ & $d f_{1}-d f_{2}$ & $d f_{2}$ & Prob $>F$ & \\
\hline & 0.9803 & 1 & 8 & 0.3511 & \\
\hline
\end{tabular}

1. Freundlich model has lower $A I C$ value and is more likely to be correct. This model is 7.2665 times more likely to be correct.

2. $A I C=N \ln \left(\frac{R S S}{N}\right)+2 p+\frac{2 p(p+1)}{N-p-1}$, where $N$ is the number of data points and $p$ is the number of free parameters to be estimated.

3. Akaike's weight $=\frac{e^{-0.5 \Delta A I C}}{1+e^{-0.5 \Delta A I C}}$, where $\triangle A I C$ is the deference between two $A I C$ values.

4. Freundlich model with lower $B I C$ seems to be correct. BIC difference $(\triangle B I C)$ less than 2 is inconclusive.

5. $\quad B I C=N \ln \left(\frac{R S S}{N}\right)+p \ln (N)$, and $\triangle B I C$ is the deference between two $B I C$ values.

6. At the 0.05 significance level, Freundlich model (simple model) is more likely to be correct.

7. $F=\frac{\left(R S S_{1}-R S S_{2}\right) /\left(d f_{1}-d f_{2}\right)}{R S S_{2} / d f_{2}}$, where $R S S_{1}$ and $d f_{1}$ are the residual sum of squares and degrees of freedom of the simple model (Freundlich model), respectively, and $R S S_{2}$ and $d f_{2}$ are the residual sum of squares and degrees of freedom of the complex model (R-P model), respectively. 

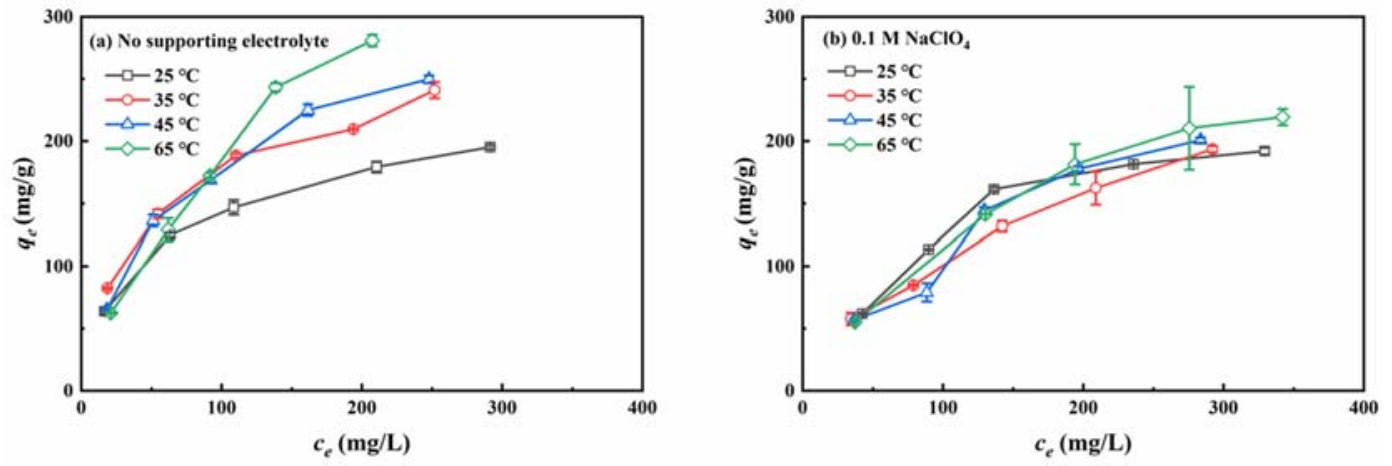

Figure S5. Adsorption isotherms of U(VI) onto OBSG at different temperature (a) without supporting electrolyte and (b) with $0.1 \mathrm{M} \mathrm{NaClO}_{4}$. For adsorption: $2 \mathrm{mg}$ OBSG/ $2 \mathrm{~mL}$ solution, $\mathrm{c}_{0}(\mathrm{U})=100-500 \mathrm{mg} / \mathrm{L}, \mathrm{t}=1 \mathrm{~h}, \mathrm{pH}=4.7$, temperature $=25-65^{\circ} \mathrm{C}$, stirrer speed $=180 \mathrm{rpm}$. 
Table S9. Parameters of the mashing process to produce BSG.

\begin{tabular}{llll}
\hline Procedure & Initial temperature $\left({ }^{\circ} \mathrm{C}\right)$ & End temperature $\left({ }^{\circ} \mathrm{C}\right)$ & Time $(\mathrm{min})$ \\
\hline Mash-in & 55 & 54.8 & 10 \\
Protein rest & 62 & 61.8 & 30 \\
Maltose rest & 68 & 67.8 & 10 \\
Sugar rest & 72 & 71.8 & 25 \\
Mash-out & 78 & 77.8 & 10 \\
\hline
\end{tabular}

Table S10. Chemical composition of BSG.

\begin{tabular}{llllllll}
\hline $\begin{array}{l}\text { Water } \\
(\%)\end{array}$ & $\begin{array}{l}\text { Ash } \\
(\%)\end{array}$ & $\begin{array}{l}\text { Acid insoluble } \\
\text { lignin (\%) }\end{array}$ & $\begin{array}{l}\text { Acid soluble } \\
\text { lignin }(\%)\end{array}$ & $\begin{array}{l}\text { Lignin } \\
(\%)\end{array}$ & $\begin{array}{l}\text { Protein } \\
(\%)\end{array}$ & $\begin{array}{l}\text { Cellulose } \\
(\%)\end{array}$ & Other (\%) \\
\hline 3.0 & 3.6 & $32.5 \pm 3.8$ & $0.34 \pm 0.01$ & $32.8 \pm 3.8$ & $29 \pm 0.6$ & $8.75 \pm 0.8$ & $22.8 \pm 5.2$
\end{tabular}

Methods: The water content and ash content $\left(20^{\circ} \mathrm{C} / \mathrm{min}\right.$, Air, $\left.40-850^{\circ} \mathrm{C}\right)$ of BSG was obtained from TG analysis. The protein content was estimated according to the $\mathrm{N}$ content by multiplying by a factor of 5.83 .

The cellulose content was measured using the method proposed by Updegraff $\mathrm{f}^{3,4}$ according to literature with minor modification. Generally, four replicates of 20 to $40 \mathrm{mg}$ BSG were weighed in $6 \mathrm{~mL}$ glass tubes with screw caps. After adding $3 \mathrm{~mL}$ of a mixture of acetic acid/water/nitric acid $(8 / 2 / 1, \mathrm{v} / \mathrm{v} / \mathrm{v})$, the suspension was heated in a boiling water bath for 30 min with occasional mixing. After cooling in an ice bath, the tubes were centrifuged for $10 \mathrm{~min}$ at $1000 \mathrm{~g}$ and the supernatant was discarded. The pellet was thoroughly re-suspended in $5 \mathrm{~mL}$ bidestilled water and centrifuged again. 
The washing process was repeated once more, and the supernatant was discarded. The remaining pellet was then incubated with $2.5 \mathrm{~mL}$ of $72 \mathrm{wt} \%$ sulphuric acid for $1 \mathrm{~h}$ with vortex every 5-10 min. The clear solution was transferred into a $10 \mathrm{~mL}$ volumetric flask and filled to the marking with water (after sufficient cooling time). For the photometric determination of cellulose, $20 \mu \mathrm{L}$ aliquots were diluted to $400 \mu \mathrm{L}$ with water and $1 \mathrm{~mL}$ of ice-cold $100 \mathrm{mg}$ anthrone in $50 \mathrm{~mL}$ sulphuric acid (95 wt \%) was added. The mixture was heated for $15 \mathrm{~min}$ in a boiling water bath, cooled in an ice bath for $2 \mathrm{~min}$ and let stand at room temperature for 10 min prior to photometric measurement at $620 \mathrm{~nm}$ against reagent blank. A cellulose stock solution for calibration was prepared by dissolving $57.4 \mathrm{mg}$ of microcrystalline cellulose in $10 \mathrm{~mL}$ of $72 \mathrm{wt} \%$ sulphuric acid and diluting to $500 \mathrm{~mL}$ with water. Dilutions in the range of $2.87 \mu \mathrm{g}$ to $28.7 \mu \mathrm{g}$ in $400 \mu \mathrm{L}$ water were prepared in duplicate and processed by anthrone assay as mentioned above.

The content of lignin was determined according to ASTM E1758-01 and method reported by Balogun et.al ${ }^{5}$. More specifically, $300 \pm 10 \mathrm{mg}$ BSG was incubated in $3 \mathrm{~mL}$ 72 wt $\% \mathrm{H}_{2} \mathrm{SO}_{4}$ for $1 \mathrm{~h}$ at $30{ }^{\circ} \mathrm{C}$, then diluted into $4 \mathrm{wt} \% \mathrm{H}_{2} \mathrm{SO}_{4}$, and subjected to a secondary hydrolysis in an autoclave reactor (DAB-3, Berghof Products+Instruments $\mathrm{GmbH})$ at $121^{\circ} \mathrm{C}$ for $1 \mathrm{~h}$. The hydrolyzed mixture was filtrated, and the obtained solid was weighted. The content of acid-insoluble lignin was obtained by subtracting the ash content from the solid content. Meanwhile, the filtrate was collected for the measurement using a UV-vis spectrometer (Lambda 25, PerkinElmer) with a quartz 
cuvette $(10 \mathrm{~mm})$ in the range of $200-250 \mathrm{~nm}$ with a resolution of $0.1 \mathrm{~nm}$. The acidsoluble lignin content was calculated according to the absorbance at $205 \mathrm{~nm}$ using an absorption coefficient of $110 \mathrm{~L} \mathrm{~g}^{-1} \mathrm{~cm}^{-1}$.

Preliminary experiment employing $\mathrm{La}^{3+}$ adsorptions were used to optimize the dosage of $\mathrm{NO}_{2}^{-}$per $\mathrm{g}$ BSG in the oxidation. Typically, $1 \mathrm{~g}$ standardized BSG was oxidized using $16 \mathrm{~mL}$ of $85 \mathrm{wt} \% \mathrm{H}_{3} \mathrm{PO}_{4}$ and different amounts of $\mathrm{NaNO}_{2}(0,0.2 \mathrm{~g}, 0.4 \mathrm{~g}, 0.6 \mathrm{~g}$, $0.8 \mathrm{~g}, 1.0 \mathrm{~g}$ ) at room temperature for $16 \mathrm{~h}$. As shown in the following Figure S3, the adsorption capacity of $\mathrm{La}^{3+}$ onto the oxidized BSG increases as the dosage of $\mathrm{NaNO}_{2}$ increases from 0 to $0.8 \mathrm{~g} / \mathrm{g} \mathrm{BSG}$, and further increase of the amount of $\mathrm{NaNO}_{2}$ added to $1.0 \mathrm{~g} / \mathrm{g}$ BSG results in no obvious improvement of the adsorption capacity. Thus, a $0.8 \mathrm{~g} \mathrm{NaNO}_{2}$ per $\mathrm{g} \mathrm{BSG}$ were used in the oxidation of BSG.

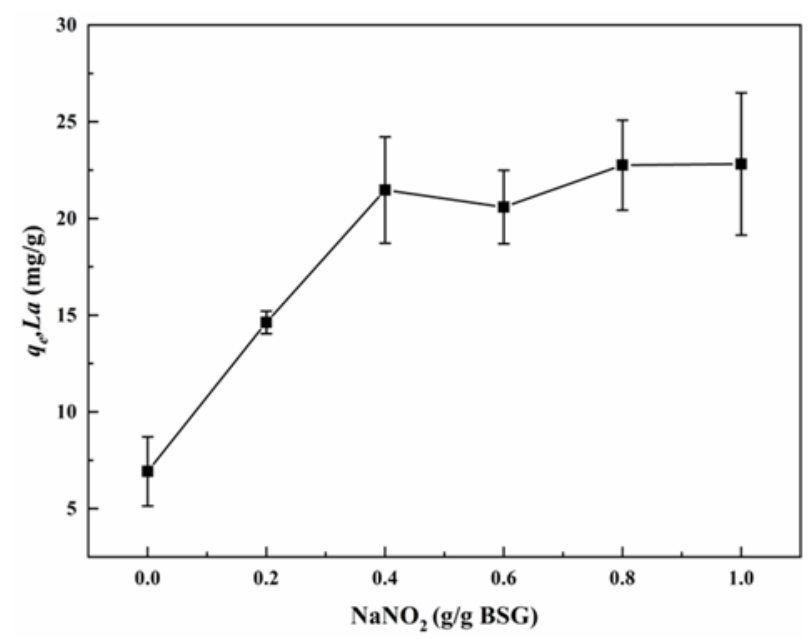

Figure S6. Adsorption capacity of $\mathrm{La}^{3+}$ in dependence of the amount of $\mathrm{NaNO}_{2}$ used in the oxidation of BSG. For adsorption: $2 \mathrm{mg}$ adsorbent/ $2 \mathrm{~mL}$ solution, $\mathrm{c}_{0}\left(\mathrm{La}^{3+}\right)=$ $100 \mathrm{mg} / \mathrm{L}, \mathrm{pH}=5.5,2 \mathrm{~h}$, room temperature. 

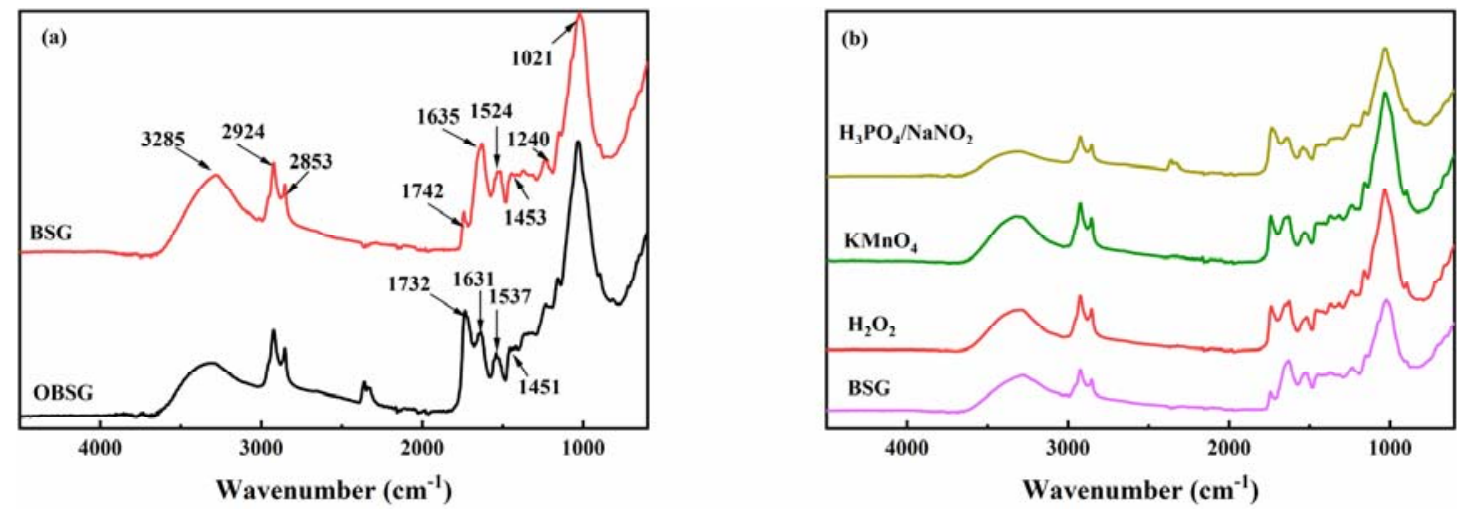

Figure S7. (a) Raw FT-IR spectra of BSG and OBSG $(<315 \mu \mathrm{m})$ and (b) Raw FT-IR spectra of oxidized products by different oxidation methods. $\mathrm{H}_{2} \mathrm{O}_{2}$ method: 2 g BSG, $10 \mathrm{~mL} 35 \mathrm{wt} \% \mathrm{H}_{2} \mathrm{O}_{2}, 0.4 \mathrm{~mL} 1 \mathrm{M} \mathrm{HCl}$, reflux at $100{ }^{\circ} \mathrm{C}$ for $2 \mathrm{~h} . \mathrm{KMnO}_{4}$ method: $1 \mathrm{~g}$ BSG, $0.18 \mathrm{~g} \mathrm{KMnO}_{4}, 20 \mathrm{~mL} 0.15 \mathrm{M} \mathrm{H}_{2} \mathrm{SO}_{4}$ at $60{ }^{\circ} \mathrm{C}$ for $2 \mathrm{~h} . \mathrm{H}_{3} \mathrm{PO}_{4} / \mathrm{NaNO}_{2}$ method: $1 \mathrm{~g} \mathrm{BSG}, 16 \mathrm{~mL} 85 \mathrm{wt} \% \mathrm{H}_{3} \mathrm{PO}_{4}, 0.8 \mathrm{~g} \mathrm{NaNO}_{2}$ at room temperature for $16 \mathrm{~h}$.

\section{Reference:}

1 J. P. Gustafsson, Visual MINTEQ ver. 3.1, Department of Land and Water Resources Engineering, KTH, SE-100 44, Stockholm, Sweden; available at the URL https://vminteq.lwr.kth.se/download/.

2 M. G. Adamson, Chemical thermodynamics of uranium, J. Nucl. Mater., 1993, 200, 154-155.

3 D. M. Updegraff, Semimicro determination of cellulose inbiological materials, Anal. Biochem., 1969, 32, 420-424.

4 S. Bauer and A. B. Ibáñez, Rapid determination of cellulose, Biotechnol. Bioeng., 2014, 111, 2355-2357.

5 A. O. Balogun, F. Sotoudehniakarani and A. G. McDonald, Thermo-kinetic, spectroscopic study of brewer's spent grains and characterisation of their pyrolysis products, J. Anal. Appl. Pyrolysis, 2017, 127, 8-16. 